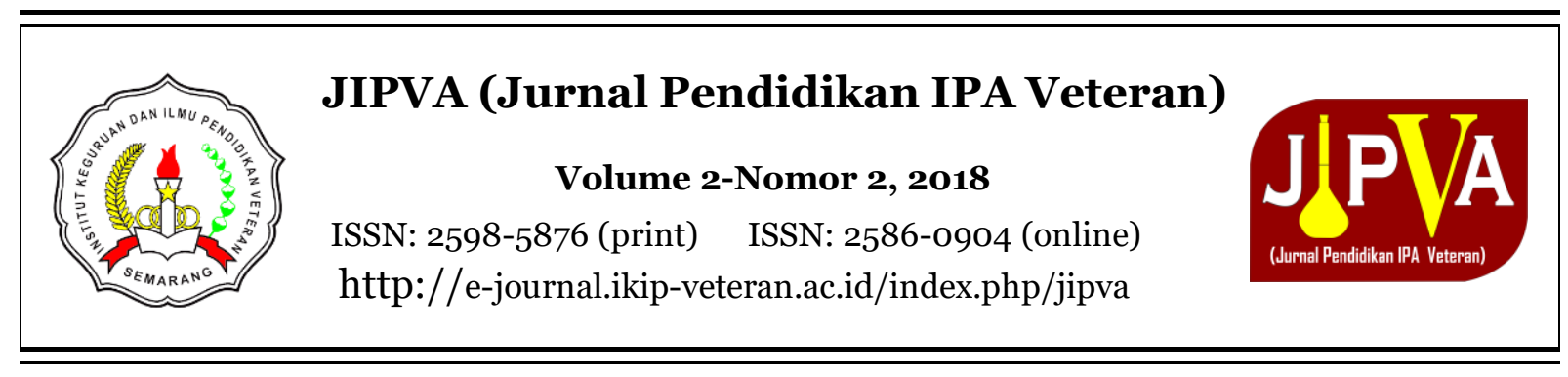

\title{
Pembelajaran IPA dan Lingkungan: Analisis Kebutuhan Media Pembelajaran pada SD, SMP, SMA di Tambun Selatan, Bekasi
}

\author{
Ilmi Zajuli Ichsan ${ }^{1 *}$, Aryani Kadarwati Dewi ${ }^{2}$, Farah Muthi Hermawati ${ }^{3}$, Enin Iriani ${ }^{4}$ \\ ${ }^{1}$ Pendidikan Biologi, FMIPA, Universitas Negeri Jakarta, Indonesia \\ ${ }^{2}$ SMP Negeri 1 Tambun Selatan, Bekasi, Jawa Barat, Indonesia \\ ${ }^{3}$ Pendidikan Fisika, FMIPA, Universitas Negeri Jakarta, Indonesia \\ ${ }^{4}$ SD Negeri Jatimulya 02, Bekasi, Jawa Barat, Indonesia \\ *Corresponding author email: ilmizajuli_bio18s2@mahasiswa.unj.ac.id \\ Received: 11 September 2018; Revised:10 Oktober ; Accepted:12Oktober2018
}

\begin{abstract}
Abstrak
Pembelajaran di era modern ini sudah banyak menggunakan teknologi dalam membantu guru dalam pembelajaran. Tujuan dari penelitian ini untuk melakukan analisis kebutuhan dan melihat peran guru dalam mengembangkan media pembelajaran IPA dan lingkungan. Metode Penelitian yang digunakan adalah metode penelitian deskriptif kualitatif yaitu dengan cara melakukan analisis kebutuhan. Penelitian dilakukan pada bulan Desember 2017 - Maret 2018. Tempat penelitian yaitu di SDN Jatimulya 02, SDN Jatimulya 07, SMPN 1 Tambun Selatan, dan SMAN 5 Tambun Selatan, Bekasi, Jawa Barat. Hasil Penelitian menunjukan bahwa media pembelajaran yang digunakan belum variatif. Guru belum berperan besar dalam mengembangkan media pembelajaran. Hal ini membuat inovasi media pembelajaran mutlak dilakukan. Kesimpulannya adalah bahwa media pembelajaran yang digunakan guru dalam pembelajaran IPA dan lingkungan di Tambun Selatan, masih perlu dikembangkan.

Kata Kunci: Media Pembelajaran, Pembelajaran IPA, Pembelajaran Lingkungan
\end{abstract}

\section{Natural Science and Environmental Learning: Need Assessment of Learning Media at School In Tambun Selatan, Bekasi}

\begin{abstract}
Learning in this modern era has used a lot of technology in helping teachers in learning. The purpose of this study is to conduct a need assessment and see the role of the teacher in developing science learning media and the environment. The research method used is descriptive qualitative research method that is by way of need assessment by conducting interviews and direct observation. SDN Jatimulya 02, SDN Jatimulya 07, SMPN 1 Tambun Selatan, dan SMAN 5 Tambun Selatan Bekasi, West Java. Research results show that learning media usage is not varied. This makes learning media innovation absolutely necessary. The conclusion is that the learning media used by teachers in science learning and the environment in South Tambun Subdistrict, Bekasi, West Java, still need more development in order to be more diverse.
\end{abstract}

Keywords: Learning Media, Science Learning, Environmental Learning

How to Cite: Ichsan, I., Dewi, A., Hermawati, F., \& Iriani, E. (2018). Pembelajaran IPA dan Lingkungan: Analisis Kebutuhan Media Pembelajaran pada SD, SMP, SMA di Tambun Selatan, Bekasi. JIPVA (Jurnal Pendidikan IPA Veteran), 2(2), 131-140. doi:10.31331/jipva.v2i2.682 


\section{PENDAHULUAN}

Perkembangan teknologi di era modern ini membuat guru harus berinovasi mengenai media pembelajaran yang digunakan dalam pembelajaran. Penggunaan media dalam pembelajaran mengalami banyak perubahan mulai dari bentuknya yang awalnya berbentuk fisik, sekarang sudah banyak media pembelajaran berbentuk online (Uzun, 2012). Pergeseran ini seharusnya membuat sebuah perubahan dalam kebiasaan guru yang mengajar, dalam hal ini pembelajaran IPA dan lingkungan. Guru sebenarnya sudah mulai menggunakan media yang berbentuk digital seperti video misalnya, namun masih belum semuanya menggunakan (Christ, Arya, \& Chiu, 2017). Bahkan, sekarang pembelajaran bisa dilakukan tanpa melalui tatap muka di kelas, melainkan bisa dilaksanakan melalui fasilitas internet (Best \& MacGregor, 2017).

Siswa dilain sisi juga sudah mulai meninggalkan kebiasaan mencatat. Hal ini dikarenakan banyak gadget yang menggantikan fungsi buku catatan. Siswa tidak perlu lagi membawa banyak buku dikarenakan sudah tersedia banyak aplikasi yang memudahkan pembelajaran. Selain itu, sekarang sudah banyak tersedia e-book yang mudah dibawa kemana-mana, yang membuat penggunaan buku cetak semakin berkurang (Ballatore \& Natale, 2016; Hsiao, Tiao, \& Chen, 2016; Muthukrishnan \& Kelley, 2017). Pergeseran ini tentu berdampak pula kepada pembelajaran di kelas. Suka ataupun tidak, pembelajaran di kelas sudah harus dilakukan sebuah inovasi (Lindfors \& Hilmola, 2016). Jika tidak dilakukan pembaharuan, maka lambat laun siswa akan bosan dalam mempelajari Ilmu Pengetahuan Alam dan lingkungan. Pengembangan media pembelajaran bisa dilakukan oleh para peneliti yang konsern di bidangnya. Selain itu pengembangan media pembelajaran bisa pula dilakukan oleh guru dengan tujuan mempermudah pembelajaran IPA dan lingkungan (Chin \& Chen, 2013).

Ketertinggalan guru dalam menggunakan media pembelajaran ini membuat pembelajaran menjadi terkesan kuno, sehingga siswa menganggap pembelajaran itu merupakan suatu hal yang membosankan. Pembelajaran yang menyenangkan bisa diperoleh dengan berbagai cara. Salah satu caranya adalah melakukan inovasi-inovasi dalam pembelajaran (Sandberg \& Ohman, 2011). Banyak sekali bentuk inovasi yang bisa dilakukan oleh guru seperti mengembangkan bahan ajar, media pembelajaran, rencana pembelajaran dan lembar kerja siswa. Semua pengembangan tersebut mengarah kepada satu tujuan yaitu untuk meningkatkan kemampuan siswa baik secara kognitif, afektif maupun psikomotor (van der Veen \& van Oers, 2017).

Kendala yang dihadapi guru tentu tidaklah sedikit. Beban bekerja yang cukup berat disertai tuntutan mengajar yang banyak sudah bukan hal yang asing lagi bagi para guru. Walaupun begitu tetaplah harus menyempatkan diri untuk turut mengembangkan media pembelajaran ini. Permasalahannya adalah terkadang guru tidak pernah melakukan inventarisasi terhadap media pembelajaran yang digunakan di sekolah tersebut. Guru terkadang juga tidak benar-benar merancang pembelajaran tersebut dengan menggunakan media yang tepat (Grosch, Berger, Gidion, \& Romeo, 2014; Yusuf, Amin, \& Nugrahaningsih, 2017). Guru sangat merasa nyaman menggunakan metode konvensional seperti ceramah untuk semua materi pada mata pelajaran IPA dan lingkungan. Hal ini tentu keliru, mengingat setiap materi memiliki karakteristik masing-masing. Guru seharusnya terus mengembangkan berbagai 
Ilmi Zajuli Ichsan, Aryani Kadarwati Dewi, Farah Muthi Hermawati, Enin Iriani

kemampuannya dalam mengajar agar bisa meningkatkan kemampuannya dalam menyampaikan materi dan mengorganisasikan kelas (Mercer-Mapstone \& Kuchel, 2017). Hal inilah yang melatarbelakangi perlunya dilakukan penelitian ini.

Tujuan dari penelitian ini adalah untuk meninjau media pembelajaran apa saja yang digunakan dalam pembelajaran IPA dan lingkungan di sekolah yang terletak di Kecamatan Tambun Selatan, Kabupaten Bekasi, Provinsi Jawa Barat pada jenjang SD, SMP, dan SMA. Media pembelajaran dilakukan pendataan. Kemudian data tersebut dikumpulkan dan dilakukan analisis. Penggunaan media tersebut juga turut dibahas dalam penelitian ini.

\section{METODE}

\section{Jenis Penelitian}

Penelitian ini merupakan penelitian deskriptif kualitatif. Pada penelitian ini dilakukan analisis kebutuhan media pembelajaran. Analisis dilakukan secara menyeluruh mengenai penggunaan media pembelajaran di sekolah tersebut.

\section{Waktu dan Tempat Penelitian}

Penelitian ini dilakukan pada bulan Desember 2017 - Maret 2018. Tempat penelitian yaitu berada di SDN Jatimulya 02, SDN Jatimulya 07, SMPN 1 Tambun Selatan, dan SMAN 5 Tambun Selatan. Semua sekolah yang menjadi tempat penelitian terletak di Kecamatan Tambun Selatan, Kabupaten Bekasi, Jawa Barat, Indonesia. Kelima Sekolah tersebut dipilih secara Purposive Sampling dengan alasan kelima sekolah tersebut merupakan sekolah unggulan dan favorit di daerah tersebut.

\section{Prosedur Penelitian}

Data diambil dengan teknik wawancara dan pengamatan secara langsung mengenai kondisi media pembelajaran di sekolah tersebut. Wawancara dilakukan kepada guru mata pelajaran IPA dan siswa. Guru diberikan pertanyaan seputar penggunaan media pembelajaran IPA di sekolah tersebut. Tahapan berikutnya adalah dengan melakukan observasi dengan cara mengamati secara langsung keadaan penggunaan media pembelajaran tersebut di sekolah, fungsi observasi juga untuk memperkuat analisis.

\section{Instrumen Penelitian}

Instrumen dibuat dengan memperhatikan 5 aspek yang terdiri dari (1) Jenis media pembelajaran yang biasa digunakan; (2) Frekuensi penggunaan media digital; (3) Kelebihan media pembelajaran yang biasa digunakan; (4) Kekurangan media pembelajaran yang biasa digunakan dan (5) Kendala guru dalam mengembangkan media pembelajaran. Kelima aspek tersebut digunakan karena dianggap aspek utama yang perlu diamati dalam pelaksannan penggunaan media pembelajaran IPA dan lingkungan di sekolah. Pengamatan dilakukan di tiap jenjang sekolah mulai dari SD, SMP, dan SMA.

\section{Teknik Analisis Data}

Data hasil wawancara dilakukan analisis secara deskriptif. Analisis diarahkan kepada alasan rendah atau tingginya penggunaan media pembelajaran di setiap jenjang. Hasil analisa data berupa uraian secara deskriptif. 


\section{HASIL DAN PEMBAHASAN}

Setelah dilakukan observasi dan wawancara kepada guru, maka diperoleh data yang telah dirangkum seperti berikut ini yang terdapat pada tabel 1. Terlihat bahwa di masing-masing jenjang terdapat perbedaan dalam penggunaan media pembelajaran pada pembelajaran IPA dan lingkungan. Perbedaan juga terlihat dari frekuensi penggunaan media pembelajaran digital di setiap jenjang. Hasil analisis kebutuhan menunjukan bahwa variasi penggunaan media pembelajaran IPA dan Lingkungan di sekolah yang terletak di Kecamatan Tambun Selatan, Bekasi masih sangat rendah.

Tabel 1. Hasil Pengamatan Media Pembelajaran IPA dan Lingkungan di Beberapa Sekolah yang Terletak di Kecamatan Tambun Selatan, Bekasi

\begin{tabular}{|c|c|c|c|c|}
\hline No & Aspek & SD & SMP & SMA \\
\hline 1 & $\begin{array}{l}\text { Jenis media } \\
\text { pembelajaran } \\
\text { yang biasa } \\
\text { digunakan }\end{array}$ & Papan tulis, Buku Teks & $\begin{array}{l}\text { Papan tulis, Buku Teks, } \\
\text { Charta }\end{array}$ & $\begin{array}{l}\text { Papan tulis, Proyektor, } \\
\text { handphone }\end{array}$ \\
\hline 2 & $\begin{array}{l}\text { Frekuensi } \\
\text { penggunaan } \\
\text { media digital } \\
\text { dalam } \\
\text { pembelajaran } \\
\text { (video, e-modul, } \\
\text { ppt, website) }\end{array}$ & 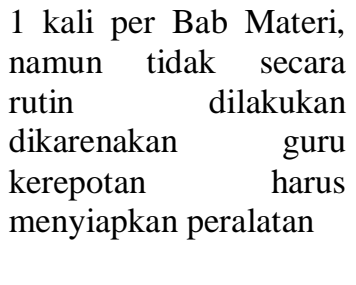 & $\begin{array}{l}\text { 2-3 kali per Bab Materi, } \\
\text { sudah secara rutin dilakukan } \\
\text { oleh guru namun konten } \\
\text { yang ditampilkan kurang } \\
\text { beragam }\end{array}$ & $\begin{array}{lr}\text { 4-6 kali per Bab Materi, } \\
\text { mulai terjadwal dengan } \\
\text { baik. Bahkan siswa sudah } \\
\text { ditugaskan } & \text { untuk } \\
\text { presentasi di depan kelas } \\
\text { menggunakan } \\
\text { digital tersebut. }\end{array}$ \\
\hline 3 & $\begin{array}{l}\text { Kelebihan media } \\
\text { pembelajaran } \\
\text { yang biasa } \\
\text { digunakan }\end{array}$ & $\begin{array}{l}\text { Penggunaan papan tulis } \\
\text { dan buku teks } r \text { sangat } \\
\text { praktis } \\
\text { memerlukan } r \text { tidak } \\
\text { sarana pendukung }\end{array}$ & $\begin{array}{l}\text { Penggunaan papan tulis dan } \\
\text { buku teks praktis, ditambah } \\
\text { charta yang mudah } \\
\text { digunakan }\end{array}$ & 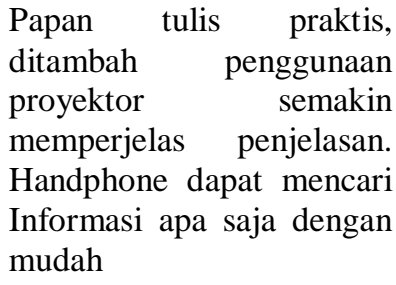 \\
\hline 4 & $\begin{array}{l}\text { Kekurangan } \\
\text { media } \\
\text { pembelajaran } \\
\text { yang biasa } \\
\text { digunakan }\end{array}$ & $\begin{array}{l}\text { Penggunaan buku teks } \\
\text { dan papan tulis sangat } \\
\text { monoton dan membuat } \\
\text { siswa bosan. }\end{array}$ & 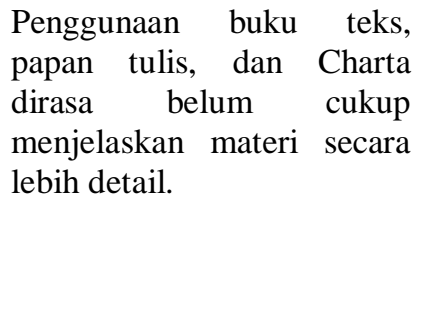 & $\begin{array}{l}\text { Penggunaan papan tulis } \\
\text { tidak terlalu membantu, } \\
\text { selain itu penggunaan } \\
\text { proyektor terkendala jika } \\
\text { listrik padam. Penggunaan } \\
\text { handphone terkendala } \\
\text { kesulitan menyediakan } \\
\text { koneksi internet. }\end{array}$ \\
\hline 5 & $\begin{array}{l}\text { Kendala guru } \\
\text { dalam } \\
\text { mengembangkan } \\
\text { media } \\
\text { pembelajaran }\end{array}$ & $\begin{array}{l}\text { Materi yang terlalu } \\
\text { banyak, sementara guru } \\
\text { IPA hanya satu orang. } \\
\text { Sehingga r tidak } \\
\text { memiliki waktu yang } \\
\text { cukup rantuk } \\
\text { mengembangkan media }\end{array}$ & $\begin{array}{l}\text { Guru IPA hanya satu orang, } \\
\text { kesulitan yang sama } \\
\text { ditambah materi yang } \\
\text { semakin dalam, sehingga } \\
\text { media yang dikembangkan } \\
\text { harus melalui proses yang } \\
\text { lebih panjang }\end{array}$ & $\begin{array}{l}\text { Guru IPA sudah terbagi ke } \\
\text { dalam bidang masing- } \\
\text { masing, akan tetapi karena } \\
\text { beban materi yang sangat } \\
\text { berat sehingga guru tidak } \\
\text { sempat melakukan } \\
\text { pengembangan. }\end{array}$ \\
\hline
\end{tabular}

Pembelajaran IPA dan lingkungan di jenjang sekolah dasar cenderung masih menggunakan media berbentuk fisik seperti papan tulis dan buku cetak yang sangat konvensional. Hal ini menandakan bahwa pengembangan media pembelajaran oleh 
guru ataupun ahli pendidikan di bidang IPA belum banyak dilakukan. Terlihat bahwa frekuensi penggunaan media pembelajaran digital yang lebih modern masih sangat minim. Padahal materi IPA dan lingkungan di jenjang SD merupakan materi dasar yang mengandung banyak konsep penting. Pembelajaran ini terjadi dikarenakan guru masih berfikir bahwa pembelajaran konvensional sudah cukup (Buldur, 2017; van der Veen \& van Oers, 2017).

Materi IPA dan lingkungan di SD yang perlu dipertimbangkan untuk dikembangkan yaitu materi pencemaran lingkungan, adaptasi makhluk hidup, gaya, listrik, dan perubahan wujud benda. Pembelajaran lingkungan memerlukan media yang sesuai dikarenakan banyak sekali masalah lingkungan yang harus diperlihatkan kepada siswa. Terkait tingkat kesulitan materi, misalnya gaya dan listrik memerlukan media dengan karakteristik khusus yang dapat membantu guru dalam menyampaikan materi secara mendalam. Pengembangan media juga harus disesuaikan dengan karakteristik kelas yang ada (Winne, Hadwin, \& Gress, 2010; Wolfson \& Funke, 2014). Terakhir berkaitan dengan perubahan wujud benda, materi ini sangat cocok sekali jika menggunakan media seperti video. Hal ini dikarenakan apabila dijelaskan melalui video, maka akan mempermudah penjelasan yang cukup kompleks (Merry, Skingsley, Mitchell, \& Orsmond, 2015; Stefanova, 2014; Yusuf et al., 2017).

Pada jenjang SMP jelas terlihat bahwa penggunaan charta mulai dilakukan yang menandakan bahwa mulai ada sedikit variasi media pembelajaran IPA dan lingkungan pada jenjang SMP. Namun, perlu dicermati bahwa penggunaan media digital masih belum sering digunakan dikarenakan kondisi sarana dan prasarana di SMP yang kebanyakan belum memadai. Aturan yang melarang siswa membawa gadget ke sekolah memperburuk keadaan tersebut. Aturan tersebut dibuat agar para siswa dapat fokus belajar dan tidak bermain gadget saat di sekolah. Namun, penting untuk diperhatikan bahwa kebutuhan siswa SMP dalam mencari sumber informasi juga perlu diakomodir. Terlebih di era modern seperti saat ini pembelajaran bisa dilakukan tanpa harus bertatap muka di kelas melalui media sosial (Evans, 2014; Saltan, 2017; Zhou, Lee, \& Sin, 2017).

Siswa SMP merupakan siswa yang memerlukan perhatian lebih dari segi media pembelajaran. Konsep-konsep dasar dari pembelajaran IPA dan lingkungan pada setiap subjeknya dijelaskan pada jenjang ini. Misal, pada pembelajaran Biologi materi pokok konsep sel dan sistem organ manusia siswa biasanya kesulitan memahami konsep tersebut apabila hanya membaca buku teks saja. Kondisi demikian tentu memerlukan bantuan media, seperti video sehingga diperlukan adanya pengembangan media pembelajaran Biologi di jenjang SMP. Pada pembelajaran Fisika, siswa SMP juga hampir secara keseluruhan berpendapat bahwa materi fisika sulit. Hal ini membuat pengembangan media pembelajaran fisika untuk keseluruhan materi di SMP diperlukan. Guru harus bisa membuat media dan memfokuskan pembelajaran kepada hakikat atau inti dari materi tersebut (Papadouris \& Constantinou, 2017). Sementara itu, untuk pembelajaran Kimia materi tentang unsur biasanya menjadi salah satu materi yang sulit. Kesulitan tersebut dapat diatasi dengan melakukan inovasi pembelajaran berbasis proyek misalnya 
yang sudah terbukti dapat membuat pembelajaran IPA semakin baik (Aslan, 2015; Lou, Chou, Shih, \& Chung, 2017; Vieira \& Tenreiro-Vieira, 2016).

Khusus pembelajaran lingkungan, media pembelajaran yang diperlukan adalah yang mampu menjelaskan keadaan lingkungan sekitar secara lebih jelas. Media pembelajaran lingkungan yang dirasa masih cocok utuk dikembangkan di jenjang SMP adalah modul cetak, video pembelajaran, dan buku saku. Terbatasnya penggunaan gadget yang ada di SMP menyebabkan pengembangan media pembelajaran berbentuk aplikasi di handphone ataupun web sulit untuk dilakukan. Pengembangan e-modul, e-book yang masih cukup mudah dibuka menggunakan laptop di sekolah sebaiknya juga dilakukan. Selain media, perlu dilakukan kegiatan-kegiatan yang membuat siswa aktif dalam pembelajaran lingkungan seperti melakukan daur ulang sampah, sehingga dapat membuat pembelajaran lingkungan lebih baik (Golitsyna, 2017; Ichsan \& Mulyani, 2018; Stover \& Ziswiler, 2017).

Beralih ke jenjang SMA, pembelajaran IPA dan lingkungan pada jenjang ini sudah lebih baik daripada jenjang dibawahnya yang ditandai dengan frekuensi penggunaan media digital yang lebih tinggi daripada jenjang SMP. Pembelajaran menggunakan media digital menyebabkan penggunaan internet juga meningkat (Reyna, Hanham, \& Meier, 2018). Namun demikian masih terdapat kelemahan dari media proyektor tersebut. Banyak guru yang hanya menggunakan proyektor sebagai pengganti papan tulis, dalam arti hanya menjadikan proyektor sebagai alat untuk menampilkan banyak tulisan yang sudah ada di buku. Seharusnya penggunaan media proyektor lebih bisa dimaksimalkan untuk menampilkan informasi-informasi lain yang tidak tersedia di buku, misalnya informasi pada web tertentu (Alias, DeWitt, \& Siraj, 2013; Hidayati \& Wuryandari, 2012; Nugraini, Choo, Hin, \& Hoon, 2013; Osho \& Williams, 2018).

Pembelajaran IPA dan lingkungan di SMA secara umum sudah lebih modern. Pada pembelajaran Biologi sudah cukup banyak video pembelajaran yang digunakan oleh guru, terutama materi yang sulit diamati misalnya tentang genetika. Namun, pembelajaran harus tetap dikembangkan untuk memperkaya media pembelajaran Biologi pada materi yang lain. Sementara itu pembelajaran lingkungan masih sedikit yang dikembangkan, sehingga sangat perlu dikembangkan. Pembelajaran Kimia sudah banyak yang menggunakan video animasi untuk melihat reaksi-reaksi kimia yang terjadi. Khusus untuk mata pelajaran Fisika perlu dikembangkan media yang lebih banyak seperti pada materi energi, elastisitas, hukum Hooke, getaran, gelombang, pegas, gerak harmonis, kalor, gaya, fluida, listrik dan materi lain yang tidak bisa disebutkan satu-persatu. Secara umum seluruh materi fisika di SMA perlu dilakukan pengembangan media pembelajaran dikarenakan pembelajaran fisika terasa sulit jika tanpa menggunakan media. Salah satu alternatif solusi yang dapat ditawarkan agar siswa lebih paham misalnya dengan menggunakan media pembelajaran peta konsep (Djanette \& Fouad, 2014). Pendekatan yang dipilih dalam pembelajaran IPA juga seharusnya yang menggunakan pendekatan ilmiah, agar pembelajaran tersebut membuat siswa semakin logis (Smith, 2014; Wieman \& Gilbert, 2015).

Selain pengembangan media, seharusnya guru sudah mulai membangun kebiasaan untuk melakukan diskusi. Kegiatan ini tentu sangat bagus bagi siswa 
Ilmi Zajuli Ichsan, Aryani Kadarwati Dewi, Farah Muthi Hermawati, Enin Iriani

dalam pembelajaran. Siswa bisa diminta untuk berdiskusi kemudian dilanjutkan membuat sebuah proyek yang berisi materi pembelajaran IPA dan lingkungan. Setelah proyek tersebut selesai maka dapat dipresentasikan di depan kelas kepada teman-temannya. Selain melatih keterampilan siswa dalam berbicara di depan teman-temannya, presentasi juga membuat siswa lebih bisa berkomunikasi satu sama lain dan menambah pengalaman siswa (Amaral \& Santos, 2018; Barber, King, \& Buchanan, 2015; Lou et al., 2017; Sadiqin, Sholahuddin, \& Santoso, 2017). Semua hal tersebut bisa terjadi jika guru memiliki peran yang aktif dalam merancang pembelajaran (Nesmith et al., 2016). Guru juga harus melakukan evaluasi yang melibatkan peran serta siswa (Ho, MacGlashan, Littman, \& Cushman, 2017).

\section{SIMPULAN DAN SARAN \\ Simpulan}

Media pembelajaran IPA dan lingkungan yang ada di sekolah yang terletak di Kecamatan Tambun Selatan, Kabupaten Bekasi, Jawa Barat, belum terlalu beragam. Para guru merasa kesulitan dalam mengembangkan media pembelajaran. Lambatnya proses pengembangan juga disebabkan guru tidak memiliki banyak waktu untuk mengembangkan media.

\section{Saran}

Kedepannnya harus dilakukan pengembangan media pembelajaran IPA dan Lingkungan dikarenakan masih sangat sedikit variasi media yang digunakan dalam pembelajaran.

\section{DAFTAR PUSTAKA}

Alias, N., DeWitt, D., \& Siraj, S. (2013). Design and Development of Webquest for Physics Module by Employing Isman Instructional Design Model. Procedia - Social and Behavioral Sciences, 103, 273-280. https://doi.org/10.1016/j.sbspro.2013.1 0.335

Amaral, J. A. A. D., \& Santos, R. J. R. L. D. (2018). Combining project-based learning and community-based research in a research methodology course: The lessons learned. International Journal of Instruction, 11(1), 47-60.

Aslan, S. (2015). Is learning by teaching effective in gaining 21 st century skills? The views of pre-service science teachers. Kuram ve Uygulamada Egitim Bilimleri, 15(6), 1441-1457. https://doi.org/10.12738/estp.2016.1.00 19

Ballatore, A., \& Natale, S. (2016). E-readers and the death of the book: Or, new media and the myth of the disappearing medium. New Media and Society, 18(10), 2379-2394. https://doi.org/10.1177/1461444815586 984

Barber, W., King, S., \& Buchanan, S. (2015). Problem based learning and authentic assessment in digital pedagogy: Embracing the role of collaborative communities. Electronic Journal of E-Learning, 13(2), 59-67. https://doi.org/10.1002/t1.7401

Best, M., \& MacGregor, D. (2017). Transitioning Design and Technology Education from physical classrooms to virtual spaces: implications for preservice teacher education. International Journal of Technology and Design Education, 27(2), 201-213. https://doi.org/10.1007/s10798-0159350-z 
Buldur, S. (2017). A longitudinal investigation of the preservice science teachers' beliefs about science teaching during a science teacher training programme. International Journal of Science Education, 39(1), 1-19.

Chin, K.-Y., \& Chen, Y.-L. (2013). A Mobile Learning Support System for Ubiquitous Learning Environments. Procedia - Social and Behavioral Sciences, $\quad 73$, 14-21. https://doi.org/10.1016/j.sbspro.2013.0 2.013

Christ, T., Arya, P., \& Chiu, M. M. (2017). Video use in teacher education: An international survey of practices. Teaching and Teacher Education, 63, 22-35.

https://doi.org/10.1016/j.tate.2016.12.0 05

Djanette, B., \& Fouad, C. (2014). Determination of University Students' Misconceptions about Light Using Concept Maps. Procedia - Social and Behavioral Sciences, 152, 582-589. https://doi.org/10.1016/j.sbspro.2014.0 9.247

Evans, C. (2014). Twitter for teaching: Can social media be used to enhance the process of learning? British Journal of Educational Technology, 45(5), 902915. https://doi.org/10.1111/bjet.12099

Golitsyna, I. (2017). Educational Process in Electronic Information-educational Environment. Procedia - Social and Behavioral Sciences, 237, 939-944. https://doi.org/10.1016/j.sbspro.2017.0 2.132

Grosch, M., Berger, R., Gidion, G., \& Romeo, M. (2014). Which Media Services do Students Use in Fact? Results of an International Empirical Survey. Procedia - Social and Behavioral Sciences, 141, 795-806. https://doi.org/10.1016/j.sbspro.2014.0 5.139

Hidayati, N., \& Wuryandari, A. I. (2012).
Media Design for Learning Indonesian in Junior High School Level. Procedia - Social and Behavioral Sciences, 67, 490-499.

https://doi.org/10.1016/j.sbspro.2012.1 1.354

Ho, M. K., MacGlashan, J., Littman, M. L., \& Cushman, F. (2017). Social is special: A normative framework for teaching with and learning from evaluative feedback. Cognition, 167, 91-106.

https://doi.org/10.1016/j.cognition.201 7.03.006

Hsiao, C.-C., Tiao, M.-M., \& Chen, C.-C. (2016). Using interactive multimedia eBooks for learning blood cell morphology in pediatric hematology. BMC Medical Education, 16(1), 290. https://doi.org/10.1186/s12909-0160816-9

Ichsan, I. Z., \& Mulyani, S. W. W. (2018). Improving Students' Motoric Skills Through Demonstration Method in Recycling Plastic Waste. JPBI (Jurnal Pendidikan Biologi Indonesia), 4(2), 189-194.

https://doi.org/10.22219/jpbi.v4i2.5890

Lindfors, E., \& Hilmola, A. (2016). Innovation learning in comprehensive education? International Journal of Technology and Design Education, 26(3), 373-389. https://doi.org/10.1007/s10798-0159311-6

Lou, S.-J., Chou, Y.-C., Shih, R.-C., \& Chung, C.-C. (2017). A Study of Creativity in $\mathrm{CaC} 2$ Steamship-derived STEM Project-based Learning. Eurasia Journal of Mathematics, Science and Technology Education, 13(6), 23872404.

https://doi.org/10.12973/eurasia.2017.0 $1231 \mathrm{a}$

Mercer-Mapstone, L., \& Kuchel, L. (2017). Core Skills for Effective Science Communication: A Teaching Resource for Undergraduate Science Education. 
Ilmi Zajuli Ichsan, Aryani Kadarwati Dewi, Farah Muthi Hermawati, Enin Iriani

International Journal of Science Education, Part B: Communication and Public Engagement, 7(2), 181201.

https://doi.org/10.1080/21548455.2015. 1113573

Merry, S., Skingsley, D., Mitchell, P., \& Orsmond, P. (2015). Biology students' perceptions of learning from video exemplars of practical techniques: some lessons for teaching strategies. Innovative Practice in Higher Education, 2(2), 1-14.

Muthukrishnan, R., \& Kelley, J. E. (2017). Depictions of sustainability in children's books. Environment, Development and Sustainability, 19(3), 955-970.

https://doi.org/10.1007/s10668-0169778-7

Nesmith, S. M., Wynveen, C. J., Dixon, E. M., Brooks, B. W., Matson, C. W., Hockaday, W. C., DeFillipo, J. E. (2016). Exploring Educators' Environmental Education Attitudes and Efficacy: Insights Gleaned from a Texas Wetland Academy. International Journal of Science Education, Part B: Communication and Public Engagement, 6(3), 303-324. https://doi.org/10.1080/21548455.2015. 1078519

Nugraini, S. H., Choo, K. A., Hin, H. S., \& Hoon, T. S. (2013). Impact of e-AV biology website for learning about renewable energy. Procedia - Social and Behavioral Sciences, 103, 860869.

https://doi.org/10.1016/j.sbspro.2013.1 0.408

Osho, G. S., \& Williams, F. (2018). An Empirical Investigation of the Impacts of Web-Based Distance Education: Evidence for Justice Studies. Journal of Educational Issues, 4(2), 15-26. https://doi.org/10.5296/jei.v4i2.13049
Papadouris, N., \& Constantinou, C. P. (2017). Integrating the epistemic and ontological aspects of content knowledge in science teaching and learning. International Journal of Science Education, 39(6), 663-682. https://doi.org/10.1080/09500693.2017. 1299950

Reyna, J., Hanham, J., \& Meier, P. (2018). The Internet explosion, digital media principles and implications to communicate effectively in the digital space. E-Learning and Digital Media, 15(1), 36-52. https://doi.org/10.1177/2042753018754 361

Sadiqin, I. K., Sholahuddin, A., \& Santoso, U. T. (2017). Students ' Difficulties on Science Learning with Prototype Problem-Solving Based Teaching and Learning Material :, 100, 279-282.

Saltan, F. (2017). Using Blogs to Improve Elementary School Students' Environmental Literacy in Science Class. European Journal of Educational Research, 6(3), 347-355. https://doi.org/10.12973/eu-jer.6.3.347

Sandberg, K. W., \& Ohman, G. (2011). Learning in innovation development. Procedia - Social and Behavioral Sciences, 28, 379-383.

Smith, T. (2014). Elementary Science Instruction: Examining a Virtual Environment for Evidence of Learning, Engagement, and 21st Century Competencies. Education Sciences, 4(1), 122-138. https://doi.org/10.3390/educsci4010122

Stefanova, T. A. (2014). Using of Training Video Films in the Engineering Education. Procedia - Social and Behavioral Sciences, 116, 1181-1186. https://doi.org/10.1016/j.sbspro.2014.0 1.366

Stover, S., \& Ziswiler, K. (2017). Impact of Active Learning Environments on 
Community of Inquiry. International Journal of Teaching and Learning in Higher Education, 29(3), 458-470. Retrieved from http://ezproxy.lib.uconn.edu/login?url= https://search.ebscohost.com/login.aspx ?direct $=$ true $\& \mathrm{db}=$ eric $\& \mathrm{AN}=\mathrm{EJ} 115076$ $0 \&$ site $=$ ehost-live

Uzun, N. (2012). A Sample of Active Learning Application in Science Education: The Thema "Cell" with Educational Games. Procedia - Social and Behavioral Sciences, 46, 29322936.

https://doi.org/10.1016/j.sbspro.2012.0 5.592

van der Veen, C., \& van Oers, B. (2017). Advances in research on classroom dialogue: learning outcomes and assessments. Learning and Instruction, 48 , $1-4$. https://doi.org/10.1016/j.learninstruc.20 17.04.002

Vieira, R. M., \& Tenreiro-Vieira, C. (2016). Fostering Scientific Literacy and Critical Thinking in Elementary Science Education. International Journal of Science and Mathematics Education, 14(4), 659-680. https://doi.org/10.1007/s10763-0149605-2

Wieman, C., \& Gilbert, S. (2015). Taking a Scientific Approach to Science Education , Part I - Research, 10(4), 152-156.

Winne, P. H., Hadwin, A. F., \& Gress, C. (2010). The learning kit project: Software tools for supporting and researching regulation of collaborative learning. Computers in Human Behavior, 26(5), 787-793. https://doi.org/10.1016/j.chb.2007.09.0 09

Wolfson, T., \& Funke, P. N. (2014). Communication, class and concentric media practices: Developing a contemporary rubric1. New Media and Society, 16(3), 363-380. https://doi.org/10.1177/1461444813481 199

Yusuf, M. M., Amin, M., \& Nugrahaningsih. (2017). Developing of Instructional Media-Based Animation Video on Enzyme and Metabolism Material. Jurnal Pendidikan Biologi Indonesia, 3(3), 254-257.

Zhou, Q., Lee, C. S., \& Sin, S. C. J. (2017). Using social media in formal learning: Investigating learning strategies and satisfaction. Proceedings of the Association for Information Science and Technology, 54(1), 472-482. https://doi.org/10.1002/pra2.2017.1450 5401051 